\title{
KUALITAS PRODUK DAN KUALITAS PELANAN SEBAGAI ANTASEDEN KEPUASAN PELANGGAN DALAM MEMBENTUK LOYALITAS PELANGGAN \\ (Studi Pada Pelanggan Waroeng Spesial Sambal "SS" Cabang Veteran Yogyakarta)
}

\author{
Alo Rahmawati Mulyana \\ mulyanarahma97@gmail.com \\ Universitas Ahmad Dahlan \\ Hendro Setyono \\ Hendro.setyono@yahoo.com \\ Universitas Ahmad Dahlan
}

\begin{abstract}
ABSTRAK
The aim of study is to analyze about effect product quality and service quality on customer's satisfaction to build customer's loyalty at Waroeng Spesial Sambal "SS" in the branch of Veteran Yogyakarta. Population in this study are all consumers who make purchases at Waroeng Spesial Sambal "SS" the branch in the branch of Veteran Yogyakarta. While the sample in this study is a portion of consumers who have made purchases at least twice in the past year. The sampling technique uses purposive sampling. The data used in this study is primary data. The number of studies in this study were sixty samples in the city of Yogyakarta which were processed using multiple linear regression analysis and mediation analysis using SPSS 20 for windows. The results of the analysis in this study are: product quality dosen't have a significant effect on customer satisfaction, service quality has a significant effect on customer satisfaction, customer satisfaction doesn't have a significant effect on customer loyalty, product quality dosen't have a significant effect on customer loyalty and service quality has a significant effect on customer loyalty of the two independentvariables dosen't indicate a mediating relationship with customer satisfaction as a mediator variable.
\end{abstract}

Keywords: product quality, service quality, customer satisfaction, customer loyalty.

\footnotetext{
PENDAHULUAN

Persaingan bisnis dewasa ini sangat ketat yang mengharuskan para pengusaha memahami pasar dan perilaku konsumen agar tetap bertahan pada usaha yang dijalankan. Menjadi organisasi yang berfokus pada konsumen adalah pilihan strategis bagi industri dan dunia usaha agar mampu bertahan di tengah situasi lingkungan ekonomi yang memperlihatkan kecenderungan, seperti fluktuasi curam, perubahan demi perubahan, persaingan tinggi, dan semakin canggihnya kualitas hidup (Lupiyoadi, 2013).
}

Bisnis kuliner merupakan salah satu dari sekian banyak bisnis yang dijalankan oleh para pengusaha di Indonesia dan merupakan bisnis jasa yang berkembang dengan pesat. Bisnis kuliner akan terus tumbuh dan berkembang hal ini dikarenakan pada dasarnya makanan merupakan kebutuhan pokok manusia yang harus dipenuhi. Hal ini juga menjadi peluang bagi para pengusaha yang bergerak dibidang kuliner.

Pemasaran di butuhkan untuk perkembangan usaha. Salah satu cara adalah dengan menciptakan kepuasan pelanggan (customer satisfaction) melalui 
peningkatan kualitas, karena pelanggan adalah fokus utama ketika kita mengungkapkan tentang kepuasan dan kualitas jasa (Lupiyoadi, 2013). Menurut Zeithmal dan Bitner (1996) dikutip dalam Lupiyoadi (2013) faktor utama penentu kepuasan pelanggan adalah persepsi pelanggan terhadap kualitas jasa. Kualitas produk (jasa) adalah sejauh mana produk (jasa) memenuhi spesifikasispesifikasinya. Kualitas menurut ISO 9000 adalah derajat yang dicapai oleh karakteristik yang inheren dalam memenuhi persyaratan. Persayaratan dalam hal ini adalah kebutuhan atau harapan yang dinyatakan, biasanya tersirat atau wajib (Lupiyoadi, 2013). Menurut Parasuraman dkk., (1998) dikutip dalam Lupiyoadi (2013) jika kenyataannya sama atau lebih dari yang diharapkan maka layanan dapat dikatakan berkualitas atau memuaskan. Sebaliknya, jika kenyataan kuran dari yang diharapkan maka layanan dapat dikatakan tidak berkualitas atau tidak memuaskan. Singkat kata, kualitas jasa dapat didefinisikan sebagai seberapa jauh perbedaan antara kenyataan dan harapan pelanggan atas layanan yang mereka terima.

Selain kualitas pelayanan, kualitas produk perlu diperhatikan untuk memuaskan konsumen. Konsep produk berpendapat bahwa konsumen menyukai produk yang menawarkan kualitas, kinerja, atau fitur inovatif terbaik (Kotler, 2009). Pendekatan yang dikemukakan Goetsch Davis menegaskan bahwa kualitas bukan hanya menekankan pada aspek hasil akhir, yaitu produk dan jasa tetapi juga menyangkut kualitas manusia, kualitas proses dan kualitas lingkungan. Sangatlah mustahil menghasilkan produk dan jasa yang berkualitas tanpa melalui manusia dan proses yang berkualitas (Yamit, 2004).
Seluruh kegiatan yang dilakukan oleh sebuah perusahaan pada akhirnya akan bermuara pada nilai yang akan diberikan oleh pelanggan mengenai kepuasan yang dirasakan (Lupiyoadi, 2013). Menurut Kotler dikutip dalam Lupiyoadi (2013) kepuasan merupakan tingkat perasaan di mana seseorang menyatakan hasil perbandingan atas kinerja produk jasa yang diterima dengan yang diharapkan. Kotler (2009) mengemukakan bahwa kepuasan juga tergantung pada kualitas produk dan jasa.

Dalam era globalisasi ini, perusahaan akan selalu menyadari akan pentingnya faktor pelanggan. Oleh karena itu, mengukur tingkat kepuasan para pelanggan sangatlah perlu, walaupun hal tersebut tidaklah semudah mengukur berat badan atau tingi badan pelanggan yang bersangkutan. Banyak manfaat bagi perusahan dengan tercapainya kepuasan pelanggan (customer satisfaction) yang tinggi, di mana akan meningkatkan loyalitas pelanggan dan mencegah perputaran (Lupiyoadi, 2013).

Loyalitas merupakan satu kata lama yang biasanya digunakan untuk menggambarkan kesetiaan dan kepatuhan terhadap negara, gerakan, atau individu. Belakangan ini loyalitas digunakan dalam konteks bisnis untuk menggambarkan kesediaan pelanggan agar senantiasa menggunakan produk perusahaan dalam jangka panjang, apalagi jika menggunkannya secara eksklusif, dan merekomendasikan produkproduk perusahaan kepada teman dan rekannya. Loyalitas pelanggan melampaui perilaku dan mencaku preferensi, kesukaan, dan itikad di masa mendatang (Lovelock, 2013). Dasar bagi loyalitas sejati terletak pada kepuasan pelanggan di mana kualitas layanan menjadi input utamanya. Pelanggan yang sangat puas atau bahkan yang menyenangi layanan 
cenderung menjadi pendukung loyal perusahaan, menggabungkan semua pembelian mereka dengan satu penyedia layanan, dan menyebarkan berita positif (Lovelock, 2013).

Salah satu bisnis kuliner yang berkembang di Yogyakarta adalah Waroeng Spesial Sambal atau lebih dikenal Waroeng "SS". Berkembangnya rumah makan ini tentu tidak terlepas dari produk dan pelayanan yang diberikan kepada konsumennya. Produk dan pelayanan ini akan mempengaruhi pada kepuasan konsumen yang pada akhirnya berdampak pada loyalitas konsumen dan peningkatan pendapatan Waroeng "SS".

Waroeng Spesial Sambal "SS" merupakan sebuah rumah makan yang memfokuskan kualitas produk serta kualitas pelayanannya kepada konsumen. Pemilik Waroeng Spesial Sambal "SS" Yoyok mengatakan bahwa bisnisnya tidak menggunakan waralaba akan tetapi membuaka cabang. Hal tersebut dijelaskannya karena waralaba hanya menguntungkan secara jangka pendek, tetapi jangka panjang sangat berisiko. Yoyok mengatakan jika menggunakan sistem waralaba untuk bisnisnya, kualitas produk dan pelayanan dilaur kendali, maka dari itu untuk menjaga kualitas produk dan pelayanan Yoyok membuka cabang untuk meminimalisir risiko. Waroeng Spesial Sambal "SS" menyediakan berbagai macam minuman dan makanan serta beberapa varian sambal yang ditawarkan kepada konsumen. Kualitas pelayanan dan kualitas produk merupakan faktor penting dalam meningkatkan daya saing. Harapan dari konsumen setiap saat selalu berubah, sehingga kualitas pelayanan dan kualitas produk yang diberikan harus disesuaikan.

Studi menemukan bahwa pelanggan akan menyusun kembali pola pengambilan keputusan berdasarkan pengalaman mereka sebelumnya saat berinteraksi dengan perusahan dan dengan kompetitor dari perusahaan tersebut. Proses membandingkan ini sedikit kompleks, karena pelanggan akan membuat perbandingan berdasarkan banyak dimensi pelayanan dan biasanya kerugian lebih dirasakan daripada manfaat yang diterima (Lupiyoadi, 2013).

Waroeng Spesial Sambal "SS" dituntut untuk dapat mengerti apa yang menjadi harapan atau keinginan konsumen dari kualitas produk dan kualitas pelayanan yang diberikan agar tercpita kepuasan bagi konsumen yang berujung pada loyalitas konsumennya, oleh karena itu Waroeng Spesial Sambal "SS" harus memperhatikan setiap hal yang dianggap penting oleh konsumen.

Pelayanan yang bertujuan memperoleh kepuasan pelanggan bukanlah suatu yang mudah untuk dilakukan, sering terdapat berbagai masalah dalam pengelolaan pelayanan sebuah perusahaan dan ketidakberhasilan memuaskan sebagian besar pelanggan mereka. Masalah yang ditemukan pada Waroeng Spesial Sambal "SS", seperti konsumen yang terkadang tidak langsung mendapatkan tempat makan karena harus menunggu karyawan membersihkan meja atau tempat makan yang masih kotor, tempat parkir yang kurang memadai, mushola yang tidak terlalu luas, serta pelayanan dan waktu penyajian produk yang kadang lama, tetapi itu tidak menyurutkan konsumen untuk datang ke Waroeng Spesial Sambal "SS". Sehingga belum diketahui faktor yang mempengaruhi kepuasan serta loyalitas konsumen.

Tujuan dari penelitian ini adalah: 1) untuk mengetahui pengaruh kualitas produk terhadap kepuasan pelanggan di Waroeng Spesial Sambal "SS" cabang 
Veteran Yogyakarta, 2) untuk mengetahui pengaruh kualitas pelayanan terhadap kepuasan pelanggan di Waroeng Spesial Sambal "SS" cabang Veteran Yogyakarta, 3) untuk mengetahui pengaruh kepuasan pelanggan terhadap loyalitas pelanggan di Waroeng Spesial Sambal "SS" cabang Veteran Yogyakarta, 4) untuk mengetahui pengaruh kualitas produk terhadap loyalitas pelanggan di Waroeng Spesial Sambal "SS" cabang Veteran Yogyakarta, 5) untuk mengetahui pengaruh kulitas pelayanan terhadap loyalitas pelanggan di Waroeng Spesial Sambal "SS" cabang Veteran Yogyakarta dan 6) untuk mengetahui kepuasan pelanggan memediasi pengaruh kualitas produk terhadap loyalitas pelanggan di Waroeng Spesial Sambal "SS" cabang Veteran Yogyakarta.

\section{REVIEW LITERATUR DAN HIPOTESIS}

\section{Landasan Teori}

1. Kualitas Produk

Menurut Lupiyoadi (2013) produk merupakan keseluruhan konsep objek atau proses yang memberikan sejumlah nilai kepada konsumen. Yang perlu diperhatikan dalam produk adalah konsumen tidak hanya membeli fisik dari produk saja, tetapi membeli manfaat dan nilai dari produk tersebut yang disebut "the offer". Utamanya, pada produk jasa, tidak dikenal munculnya peralihan kepemilikan dari penyedia jasa kepada konsumen.

2. Kualitas Makanan

Menurut Margareta dan Edwin (2012) dikutip dalam Sulistyaningrum (2014), kualitas makanan merupakan peranan penting dalam pemutusan pembelian konsumen, sehingga dapat diketahui bila kualitas makanan meningkat, maka keputusan pembelian akan meningkat juga.

3. Dimensi Kualitas Makanan

Menurut Marsum (2005) dikutip dalam Sulistyaningrum (2014), dimensi kualitas makanan terbagi dalam:

1. Flavour (rasa)

2. Consistency (ketetapan)

3. Texture/Farm/Shape

(susunan/bentuk/potongan)

4. Nutritional Content (kandungan gizi)

5. Visual Appeal (daya penarik lewat ketajaman mata)

6. Aromatic Appeal (daya penarik lewat aroma)

7. Temperature (suhu)

4. Kualitas Pelayanan

Menurut Parasuraman (1998) dikutip dalam Lupiyoadi (2013), jika kenyataannya sama atau lebih dari yang diharapkan maka layanan dapat dikatakan berkualitas atau memuaskan. Sebaliknya, jika kenyataan kurang dari yang diharapkan maka layanan dapat dikatakan tidak berkualitas atau tidak memuaskan. Singkat kata, kualitas jasa dapat didefinisikan sebagai seberapa jauh perbedaan antara kenyataan dan harapan pelanggan atas layanan yang mereka terima.

5. Dimensi Kualitas Jasa

Menurut Zeithaml dan Parasuraman (1985) dikutip dalam Yamit (2004), dimensi kualitas jasa terbagi dalam:

1. Tangibles (bukti langsung)

2. Reliability (kehandalan)

3. Responsiveness (daya tangkap)

4. Assurance (jaminan)

5. Empaty

6. Kepuasan Pelanggan

$$
\text { Menurut Soedjas }
$$
pelanggan yang puas cenderung akan menggunakan kembali (berulangulang), bahkan menjadi loyal. Sebaliknya, apabila titik temu antara 
kebutuhan, keinginan, harapan dan produk atau jasa yang diterima tidak tercapai, tentu yang terjadi adalah kekecewaan. Kepuasan salah satunya dapat dipahami sebagai segala sesuatu yang mampu memenuhi keinginan (want) atau kebutuhan (need) dan harapan pelanggan (expectation) lewat produk yang dikonsumsi.

Menurut Yamit (2004) jika harapan pelanggan sesuai dengan apa yang dialami dan dirasakannya, bahkan mungkin apa yang dialami dan dirasakan melebihi harapannya sudah dapat dipastikan pelanggan tersebut akan merasa puas. Bila yang dialami dan dirasakan konsumen tidak sesuai harapannya, misalnya pelayanan tidak ramah, tidak tanggap dan masakannya tidak enak, sudah dapat dipastikan pelanggan tidak merasa puas.

7. Dimensi Kepuasan Pelanggan

Menurut Lupiyoadi (2001) dikutip dalam Sulistyaningrum (2014), dimensi kepuasan pelanggan terbadi dalam:

1. Kualitas Produk

2. Harga

3. Service Quality

4. Biaya dan kemudahan mendapatkan produk

8. Loyalitas Pelanggan

Loyalitas merupakan satu kata lama yang biasanya digunakan untuk menggambarkan kesetiaan dan kepatuhan terhadap negara, gerakan, atau individu. Belakangan ini loyalitas digunakan dalam konteks bisnis, untuk menggambarkan kesediaan pelanggan agar senantiasa menggunakan produk perusahaan dalam jangka panjang, apalagi jika menggunkannya secara eksklusif dan merekomendasikan produk-produk perusahaan kepada teman dan rekannya. Loyalitas pelanggan melampaui perilaku dan mencakup preferensi, kesukaan, dan itikad di masa mendatang (Lovelock,
Wirtz dan Mussry; 2013). Dasar bagi loyalitas sejati terletak pada kepuasan pelanggan, dimana kualitas layanan menjadi input utamanya. Pelanggan yang sangat puas atau bahkan yang menyenangi layanan cenderung menjadi pendukung loyal perusahaan, menggabungkan semua pembelian mereka dengan satu penyedia layanan, dan menyebarkan berita positif (Lovelock, 2013).

9. Pengukuran Loyalitas

Menurut Griffin (2005) dikutip dalam Irnandha (2016) loyalitas pelanggan tampaknya merupakan ukuran yang lebih dapat diandalkan untuk memprediksi pertumbuhan penjualan dan keuangan. Berbeda dari kepuasan, yang merupakan sikap,loyalitas dapat didefinisikan berdasarkan perilaku membeli. Pelanggan yang loyal adalah orang yang:

1. Melakukan pembelian ulang

2. Membeli antar lini produk atau jasa

3. Mereferensikan kepada orang lain

4. Menunjukan kekebalan terhadap pesaing

\section{Hipotesis}

H1: kualitas produk berpengaruh positif dan signifikan terhadap kepuasan pelanggan.

$\mathrm{H} 2$ : kualitas pelayanan berpengaruh positif dan signifikan terhadap kepuasan pelanggan.

H3: kepuasan pelanggan berpengaruh positif dan signifikan terhadap loyalitas pelanggan.

H4: kualitas produk berpengaruh positifdan signifikan terhadap loyalitas pelanggan.

H5: kualitas pelayanan berpengaruh positif dan signifikan terhadap loyalitas pelanggan.

H6: kepuasan pelanggan memediasi pengaruh kualitas produk terhadap loyalitas pelanggan. 
H7: kepuasan pelanggan memediasi pengaruh kualitas pelayanan terhadap loyalitas pelanggan.

\section{METODE PENELITIAN}

Jenis penelitian yang digunakan adalah sampling non peluang (non probability sampling) dan teknik sampling yang digunakan yaitu purposive sampling. Variabel yang diteliti adalah Kualitas produk, Kualitas pelayanan, Kepuasan pelanggan dan Loyalitas pelanggan. Sampel yang diambil dalam penelitian ini sebanyak 60 orang responden yang merupakan pelanggan Waroeng Spesial Sambal "SS" cabang Veteran Yogyakarta yang telah membeli dan menkonsumsi produk minimal 2 kali dalam satu tahun terakhir. Data dikumpulkan dengan menggunakan kuesioner yang kemudian dianalisis dengan analisis deskriptif dan regresi linear berganda. Hasil uji validitas dan reliabilitas menunjukkan bahwa data yang diperoleh adalah valid dan reliable, sehingga data yang diperoleh pada penelitian ini adalah layak untuk diuji.

Hasil uji validitas menunjukkan nilai factor loading > 0,5 dan membentuk dalam satu komponen sehingga dinyatakan valid. Reliabilitas diketahui pada variabel $\mathrm{X} 1=0,724$; $\mathrm{X} 2=0,866 ; \quad \mathrm{Z}=0,726 ; \quad \mathrm{Y}=0,820 ; \quad$ semua menunjukkan angka $>0,6$ sehingga dinyatakan reliable (Arikunto, 2008) dikutip di dalam Irnandha (2016). Variabel Independen dalam penelitian ini adalah: Kualitas produk (X1) dan Kualitas Pelayanan (X2). Variabel Mediator: Kepuasan pelanggan (Z). Variabel Dependen: Loyalitas pelanggan (Y).

\section{HASIL PENELITIAN DAN PEMBAHASAN}

\section{Hasil Analisis Responden}

Responden dalam penelitian ini adalah pelanggan yang pernah melakukan pembelian minimal 2 (dua) kali dalam 1 (satu) tahun terakhir di Waroeng Spesial Sambal "SS" cabang Veteran Yogyakarta dan berusia minimal 17 tahun. Identitas tentang responden tersebut meliputi jenis kelamin, usia, pendidikan terakhir, pekerjaan, pendapatan perbulan dan frekuensi berkunjung ke restoran Waroeng Spesial Sambal "SS" cabang Veteran Yogyakarta dalam 1 (satu) tahun terakhir.

Data deskripsi tentang identitas responden meliputi jenis kelamin, usia, pendidikan terakhir, pekerjaan, pendapatan perbulan dan frekuensi berkunjung. Berikut penjelasan identitas responden secara lengkap: 
Deskripsi Responden

\begin{tabular}{|c|c|c|c|c|}
\hline No. & Keter & angan & Frekuensi & Persentase \\
\hline 1. & Jenis Kelamin & 1. Laki-laki & 28 & 46,7 \\
\hline & & 2. Perempuan & 32 & 53,3 \\
\hline 2. & Usia & 1.17-23 tahun & 32 & 53,3 \\
\hline & & 2.24-30 tahun & 11 & 18,3 \\
\hline & & 3.31-37 tahun & 3 & 5,0 \\
\hline & & 4. 38-44 tahun & 10 & 16,7 \\
\hline & & 5. 45-51 tahun & 4 & 6,7 \\
\hline & & 6. Lain-lain & 0 & 0 \\
\hline 3. & Pendidikan Terakhir & 1.SLTP & 6 & 10,0 \\
\hline & & 2. SLTA & 37 & 61,7 \\
\hline & & 3. Diploma & 0 & 0 \\
\hline & & 4. Sarjana (S1) & 11 & 18,3 \\
\hline & & 5. Pascasarjana (S2) & 3 & 5,0 \\
\hline & & 6. Lain-lain & 3 & 5,0 \\
\hline 4. & Pekerjaan & 1. Pelajar & 1 & 1,7 \\
\hline & & 2. Mahasiswa & 28 & 46,7 \\
\hline & & 3.PNS & 5 & 8,3 \\
\hline & & 4. Pegawai Swasta & 14 & 23,3 \\
\hline & & 5. Wiraswasta & 4 & 6,7 \\
\hline & & 6. Lain-lain & 8 & 13,3 \\
\hline 5. & Pendapatan & 1.<Rp1.000.000,- & 14 & 23,3 \\
\hline & & $\begin{array}{l}\text { 2. Rp1.000.000,- } \\
\text { sampai }\end{array}$ & 19 & 31,7 \\
\hline & & Rp2.000.000,- & & \\
\hline & & $\begin{array}{l}\text { 3. Rp2.000.001,- } \\
\text { sampai }\end{array}$ & 7 & 11,7 \\
\hline & & $\begin{array}{r}\text { Rp4.000.000,- } \\
\text { 4. Rp4.000.001,- }\end{array}$ & 10 & 16,7 \\
\hline & & $\begin{array}{l}\text { sampai } \\
\text { Rp6.000.000,- }\end{array}$ & & \\
\hline & & 5. Rp6.000.001,- & 3 & 5,0 \\
\hline & & $\begin{array}{l}\text { sampai } \\
\text { Rp8.000.000,- }\end{array}$ & & \\
\hline & & 6. > Rp8.000.000,- & 7 & 11,7 \\
\hline 6. & Frekuensi & $1.2-3$ kali & 17 & 28,3 \\
\hline & & & & \\
\hline & Berkunjung & $2.4-5$ kali & 19 & 31,7 \\
\hline & & 3.6-7 kali & 8 & 13,3 \\
\hline & & 4.8-9 kali & 3 & 5,0 \\
\hline & & 5.10-11 kali & 1 & 1,7 \\
\hline & & 6.>11 kali & 12 & 20,0 \\
\hline
\end{tabular}

Berdasarkan tabel di atas, menunjukkan bahwa responden dalam penelitian ini merupakan responden dengan jenis kelamin dari 60 (enam puluh) responden terdiri dari laki-laki sebanyak 28 orang atau 46,7 persen dan perempuan sebanyak 32 orang atau 53,3 persen.

Usia responden dalam penelitian ini terdiri dari yang berusia 17-23 tahun sebanyak 32 orang atau 53,3 persen, yang berusia 24-30 tahun sebanyak 11oarang atau 18,3 persen, yang berusia 31-37 tahun sebanyak 3 orang atau 5,0 persen, yang berusia 38-44 tahun sebanyak 10 orang atau 16,7 persen dan yang berusia
45-51 tahun sebanyak 4 orang atau 6,7 persen.

Pendidikan terakhir responden terdiri dari SLTP sebanyak 6 orang atau 10,0 persen, SLTA sebanyak 37 orang atau 61,7 persen, sarjana (S1) sebanyak 11 orang atau 18,3 persen, pascasarjana (S2) sebanyak 3 orang atau 5,0 persen dan lain-lain sebanyak 3 orang atau 5,0 persen.

Pekerjaan yang dijadikan sampel terdiri dari pelajar sebanyak 1 orang atau 1,7 persen, mahasiswa sebanyak 28 orang atau 46,7 persen, PNS sebanyak 5 orang atau 8,3 persen, pegawai swasta sebanyak 14 orang atau 23,3 persen, wiraswata sebanyak 4 orang atau 6,7 persen dan lain-lain sebanyak 8 orang atau 13,3 persen.

Pendapatan dari responden antara lain < Rp1.000.000,- sebanyak 14 orang atau 23,3 persen, Rp1.000.000,- sampai Rp.2.000.000,- sebanyak 19 orang atau 31,7 persen, Rp2.000.001,- sampai Rp4.000.000,- sebanyak 7 orang atau 11,7 persen, Rp4.000.001,- sampai Rp6.000.000,- sebanyak 10 orang atau 16,7 persen, Rp6.000.001,- sampai Rp8.000.000,- sebanyak 3 orang atau 5,0 persen dan > Rp8.000.000,sebanyak 7 orang atau 11,7 persen.

Frekuensi responden berkunjung ke restoran Waroeng Spesial Sambal "SS" cabang Veteran Yogyakarta dalam 1 (satu) tahun terakhir yaitu, 2-3 kali sebanyak 17 orang atau 28,3 persen, 4-5 kali sebanyak 19 orang atau 31,7 persen, 6-7 kali sebanyak 8 orang atau 13,3 persen, 8-9 kali sebanyak 3 orang atau 5,0 persen, 10-11 sebanyak satu orang atau 1,7 persen dan > 11 kali sebanyak 12 orang atau 20,0 persen. 


\section{Hasil Penelitian}

1. Hasil Uji Validitas

a. Hasil Uji Validitas Kualitas Produk

Tabel Hasil Uji Validitas Variabel Kualitas Produk

\begin{tabular}{|c|c|c|c|}
\hline \multirow{2}{*}{} & \multicolumn{3}{|c|}{ Component } \\
\cline { 2 - 4 } & 1 & 2 & 3 \\
\hline Kl_Pro1 & 0,482 & 0,501 & 0,094 \\
\hline Kl_Pro2 & 0,728 & 0,183 & 0,325 \\
\hline Kl_Pro3 & 0,443 & 0,317 & $-0,350$ \\
\hline Kl_Pro4 & 0,306 & 0,634 & 0,066 \\
\hline Kl_Pro5 & 0,385 & $-0,356$ & 0,650 \\
\hline Kl_Pro6 & 0,637 & 0,130 & $-0,439$ \\
\hline Kl_Pro7 & 0,711 & $-0,254$ & 0,338 \\
\hline Kl_Pro8 & 0,670 & $-0,386$ & $-0,375$ \\
\hline Kl_Pro9 & 0,702 & 0,101 & 0,015 \\
\hline Kl_Pro10 & 0,420 & $-0,683$ & $-0,279$ \\
\hline
\end{tabular}

Dari hasil output diatas terlihat membentuk 3 (tiga) komponen, sedangkan yang diharapkan hanya membentuk 1 (satu) komponen saja. Maka dari itu, proses analisis harus diulang dengan cara mengeluarkan item-item yang dianggap tidak valid yaitu yang memiliki Measure of Sampling Adequacy (MSA) paling kecil dengan melihat output pada tabel Anti-images Matricespada output SPSS dibagian Anti-image Corellation. Terlihat bahwa item Kl_Pro5 memiliki MSA sebesar 0,327 . Dengan demikian item tersebut yaitu pernyataan nomor 5 dari variabel kualitas produk dikeluarkan dari analisis karena dinyatakan tidak valid.

Tabel Hasil Uji Validitas Variabel Kualitas Produk

\begin{tabular}{|c|c|c|c|}
\hline \multirow{2}{*}{} & \multicolumn{3}{|c|}{ Component } \\
\cline { 2 - 4 } & 1 & 2 & 3 \\
\hline Kl_Pro1 & 0,519 & 0,455 & $-0,316$ \\
\hline Kl_Pro2 & 0,710 & 0,226 & $-0,067$ \\
\hline Kl_Pro3 & 0,467 & 0,250 & 0,715 \\
\hline Kl_Pro4 & 0,324 & 0,638 & $-0,093$ \\
\hline Kl_Pro6 & 0,664 & 0,026 & 0,414 \\
\hline Kl_Pro7 & 0,676 & $-0,214$ & $-0,466$ \\
\hline Kl_Pro8 & 0,682 & $-0,502$ & $-0,020$ \\
\hline Kl_Pro9 & 0,715 & 0,056 & $-0,110$ \\
\hline Kl_Pro10 & 0,395 & $-0,735$ & 0,102 \\
\hline
\end{tabular}

Dari hasil output di atas terlihat membentuk 3 (tiga) komponen, sedangkan yang diharapkan hanya membentuk 1 (satu) komponen saja. Maka dari itu, proses analisis harus diulang dengan cara mengeluarkan item-item yang dianggap tidak valid yaitu yang memiliki Measure of Sampling Adequacy (MSA) paling kecil dengan melihat output pada tabel Anti-images Matricespada output SPSS dibagian Anti-image Corellation. Terlihat bahwa item Kl_Pro4 memiliki MSA sebesar 0,482. Dengan demikian item tersebut yaitu pernyataan nomor 4 dari variabel kualitas produk dikeluarkan dari analisis karena dinyatakan tidak valid.

Hasil Uji Validitas Variabel Kualitas Produk

\begin{tabular}{|c|c|c|c|}
\hline \multirow{2}{*}{} & \multicolumn{3}{|c|}{ Component } \\
\cline { 2 - 4 } & 1 & 2 & 3 \\
\hline Kl_Pro1 & 0,481 & 0,466 & $-0,343$ \\
\hline Kl_Pro2 & 0,712 & 0,438 & $-0,144$ \\
\hline Kl_Pro3 & 0,463 & 0,421 & 0,660 \\
\hline Kl_Pro6 & 0,647 & $-0,033$ & 0,457 \\
\hline Kl_Pro7 & 0,693 & $-0,158$ & $-0,467$ \\
\hline Kl_Pro8 & 0,709 & $-0,517$ & 0,025 \\
\hline Kl_Pro9 & 0,708 & 0,105 & 0,122 \\
\hline Kl_Pro10 & 0,449 & $-0,686$ & 0,128 \\
\hline
\end{tabular}

Dari hasil output diatas terlihat membentuk 3 (tiga) komponen, sedangkan yang diharapkan hanya membentuk 1 (satu) komponen saja. Maka dari itu proses analisis harus diulang dengan cara mengeluarkan itemitem yang dianggap tidak valid yaitu yang memiliki Measure of Sampling Adequacy (MSA) paling kecil dengan melihat output pada tabel Anti-images Matricespada output SPSS dibagian Anti-image Corellation. Terlihat bahwa item Kl_Pro3 memiliki MSA sebesar 0,595. Dengan demikian item tersebut yaitu pernyataan nomor 3 dari variabel kualitas produk 
dikeluarkan dari analisis karena dinyatakan tidak valid.

Hasil Uji Validitas Variabel Kualitas Produk

\begin{tabular}{|c|c|c|}
\hline \multirow{2}{*}{} & \multicolumn{2}{|c|}{ Component } \\
\cline { 2 - 3 } & 1 & 2 \\
\hline Kl_Pro1 & 0,468 & $-0,560$ \\
\hline Kl_Pro2 & 0,684 & $-0,487$ \\
\hline Kl_Pro6 & 0,618 & 0,128 \\
\hline Kl_Pro7 & 0,743 & $-0,037$ \\
\hline Kl_Pro8 & 0,740 & 0,496 \\
\hline Kl_Pro9 & 0,714 & $-0,185$ \\
\hline Kl_Pro10 & 0,478 & 0,689 \\
\hline
\end{tabular}

Dari hasil output diatas terlihat membentuk 2 (dua) komponen, sedangkan yang diharapkan hanya membentuk 1 (satu) komponen saja. Maka dari itu proses analisis harus diulang dengan cara mengeluarkan itemitem yang dianggap tidak valid yaitu yang memiliki Measure of Sampling Adequacy (MSA) paling kecil dengan melihat output pada tabel Anti-images Matricespada output SPSS dibagian Anti-image Corellation. Terlihat bahwa item Kl_Pro10 memiliki MSA sebesar 0,625. Dengan demikian item tersebut yaitu pernyataan nomor 10 dari variabel kualitas produk dikeluarkan dari analisis karena dinyatakan tidak valid.

Hasil Uji Validtas Variabel Kualitas Produk

\begin{tabular}{|c|c|c|}
\hline \multirow{2}{*}{} & \multicolumn{2}{|c|}{ Component } \\
\cline { 2 - 3 } & 1 & 2 \\
\hline Kl_Pro1 & 0,521 & 0,646 \\
\hline Kl_Pro2 & 0,734 & 0,411 \\
\hline Kl_Pro6 & 0,620 & $-0,451$ \\
\hline Kl_Pro7 & 0,747 & $-0,047$ \\
\hline Kl_Pro8 & 0,673 & $-0,480$ \\
\hline Kl_Pro9 & 0,739 & 0,000 \\
\hline
\end{tabular}

Dari hasil output diatas terlihat membentuk 2 (dua) komponen sedangkan yang diharapkan hanya membentuk 1 (satu) komponen saja. Maka dari itu proses analisis harus diulang dengan cara mengeluarkan itemitem yang dianggap tidak valid yaitu yang memiliki Measure of Sampling Adequacy (MSA) paling kecil dengan melihat output pada tabel Anti-images Matricespada output SPSS dibagian Anti-image Corellation. Terlihat bahwa item Kl_Pro8 memiliki MSA sebesar 0,694. Dengan demikian item tersebut yaitu pernyataan nomor 8 dari variabel kualitas produk dikeluarkan dari analisis karena dinyatakan tidak valid.

Hasil Uji Validitas Variabel Kualitas Produk

\begin{tabular}{|c|c|}
\hline & Component \\
\cline { 2 - 2 } & 1 \\
\hline Kl_Pro1 & 0,576 \\
\hline Kl_Pro2 & 0,807 \\
\hline Kl_Pro6 & 0,580 \\
\hline Kl_Pro7 & 0,723 \\
\hline Kl_Pro9 & 0,754 \\
\hline
\end{tabular}

Pada tabel di atas menunjukkan variabel kualitas produk membentuk 1 (satu) komponen dengan 5 (lima) item pernyataan yang tersisa yaitu Kl_Pro1, Kl_Pro2, Kl_Pro6, Kl_Pro7 dan Kl_Pro9, kemudian setiap item memiliki nilai factor loading > 0,50, sehingga kelima item pernyataan tersebut dianggap valid.

b. Hasil Uji Validitas Kualitas Pelayanan

Hasil Uji Validitas Variabel Kualitas Pelayanan

\begin{tabular}{|c|c|c|c|c|c|}
\hline \multirow{2}{*}{} & \multicolumn{5}{|c|}{ Component } \\
\cline { 2 - 6 } & 1 & 2 & 3 & 4 & 5 \\
\hline $\mathrm{Kl}$ Pell & 0,629 & $-0,009$ & 0,046 & 0,008 & $-0,251$ \\
\hline $\mathrm{Kl}$ Pel2 & 0,805 & 0,116 & $-0,098$ & $-0,022$ & $-0,228$ \\
\hline $\mathrm{Kl}$ Pel3 & 0,323 & $-0,300$ & 0,428 & 0,545 & $-0,102$ \\
\hline $\mathrm{Kl}$ Pel4 & 0,632 & 0,183 & $-0,285$ & 0,363 & 0,458 \\
\hline
\end{tabular}




\begin{tabular}{|c|c|c|c|c|c|}
\hline $\mathrm{Kl}$ Pel5 & 0,605 & $-0,074$ & 0,124 & 0,554 & 0,229 \\
\hline $\mathrm{Kl} \mathrm{Pel6}$ & 0,620 & $-0,337$ & $-0,344$ & $-0,025$ & 0,172 \\
\hline $\mathrm{Kl} \mathrm{Pel} 7$ & 0,669 & $-0,353$ & $-0,022$ & $-0,349$ & 0,117 \\
\hline $\mathrm{Kl}$ Pel8 & 0,444 & $-0,704$ & 0,262 & $-0,158$ & $-0,173$ \\
\hline $\mathrm{Kl} \mathrm{Pel} 9$ & 0,678 & $-0,305$ & 0,097 & $-0,116$ & 0,238 \\
\hline Kl Pell10 & 0,692 & 0,136 & 0,333 & 0,252 & $-0,206$ \\
\hline Kl Pell1 & 0,361 & 0,636 & 0,307 & 0,060 & $-0,184$ \\
\hline Kl Pell12 & 0,718 & 0,094 & $-0,399$ & 0,090 & $-0,215$ \\
\hline Kl Pell13 & 0,660 & 0,184 & $-0,259$ & $-0,115$ & $-0,253$ \\
\hline Kl Pell14 & 0,649 & 0,379 & $-0,384$ & $-0,089$ & $-0,023$ \\
\hline Kl Pell5 & 0,815 & $-0,187$ & $-0,009$ & $-0,189$ & $-0,012$ \\
\hline $\mathrm{Kl}$ Pell6 & 0,487 & 0,263 & 0,533 & $-0,345$ & $-0,074$ \\
\hline Kl_Pell7 & 0,458 & 0,368 & 0,383 & $-0,294$ & 0,583 \\
\hline
\end{tabular}

Dari hasil output diatas terlihat membentuk 5 (lima) komponen, sedangkan yang diharapkan hanya membentuk 1 (satu) komponen saja. Maka dari itu proses analisis harus diulang dengan cara mengeluarkan itemitem yang dianggap tidak valid yaitu yang memiliki Measure of Sampling Adequacy (MSA) paling kecil dengan melihat output pada tabel Anti-images Matricespada output SPSS dibagian Anti-image Corellation. Terlihat bahwa item Kl_Pel16 memiliki MSA sebesar 0,389. Dengan demikian item tersebut yaitu pernyataan nomor 16 dari variabel kualitas pelayanan dikeluarkan dari analisis karena dinyatakan tidak valid.
Hasil Uji Validitas Variabel Kualitas Pelayanan

\begin{tabular}{|c|c|c|c|c|c|}
\hline & \multicolumn{5}{|c|}{ Component } \\
\hline & 1 & 2 & 3 & 4 & 5 \\
\hline Kl Pell & 0,622 & 0,019 & 0,014 & $-0,154$ & $-0,174$ \\
\hline $\mathrm{Kl} \mathrm{Pel2}$ & 0,801 & $-0,134$ & $-0,087$ & $-0,081$ & $-0,209$ \\
\hline $\mathrm{Kl} \mathrm{Pel3}$ & 0,324 & 0,339 & 0,603 & $-0,293$ & $-0,071$ \\
\hline $\mathrm{Kl} \mathrm{Pel4}$ & 0,652 & $-0,270$ & 0,013 & $-0,200$ & 0,495 \\
\hline $\mathrm{Kl} \mathrm{Pel5}$ & 0,612 & 0,058 & 0,375 & $-0,405$ & 0,345 \\
\hline $\mathrm{Kl} \mathrm{Pel6}$ & 0,635 & 0,268 & $-0,359$ & $-0,185$ & 0,255 \\
\hline $\mathrm{Kl} \mathrm{Pel7}$ & 0,679 & 0,341 & $-0,178$ & 0,366 & 0,026 \\
\hline Kl Pel8 & 0,448 & 0,738 & 0,082 & 0,199 & $-0,245$ \\
\hline $\mathrm{Kl} \mathrm{Pel9}$ & 0,684 & 0,304 & 0,044 & 0,260 & 0,164 \\
\hline $\mathrm{Kl}$ Pello & 0,687 & $-0,104$ & 0,473 & 0,019 & $-0,262$ \\
\hline $\mathrm{Kl}$ Pell1 & 0,340 & $-0,581$ & 0,400 & 0,177 & $-0,259$ \\
\hline $\mathrm{Kl}$ Pell2 & 0,725 & $-0,169$ & $-0,307$ & $-0,341$ & $-0,111$ \\
\hline $\mathrm{Kl}$ Pel13 & 0,669 & $-0,240$ & $-0,203$ & 0,095 & $-0,318$ \\
\hline $\mathrm{Kl}$ Pell14 & 0,657 & $-0,453$ & $-0,285$ & 0,037 & $-0,048$ \\
\hline $\mathrm{Kl}$ Pell5 & 0,805 & 0,194 & $-0,144$ & 0,078 & $-0,018$ \\
\hline $\mathrm{Kl}$ Pell7 & 0,428 & $-0,281$ & 0,256 & 0,600 & 0,441 \\
\hline
\end{tabular}

terlihat membentuk 5 (lima) komponen, sedangkan yang diharapkan hanya membentuk 1 (satu) komponen saja. Maka dari itu proses analisis harus diulang dengan cara mengeluarkan itemitem yang dianggap tidak valid yaitu yang memiliki Measure of Sampling Adequacy (MSA) paling kecil dengan melihat output pada tabel Anti-images Matricespada output SPSS dibagian Anti-image Corellation. Terlihat bahwa item K1_Pel3 memiliki MSA sebesar 0,483. Dengan demikian item tersebut yaitu pernyataan nomor 3 dari variabel kualitas pelayanan dikeluarkan dari analisis karena dinyatakan tidak valid. 
Hasil Uji Validitas Variabel Kualitas Pelayanan

\begin{tabular}{|c|c|c|c|c|c|}
\hline & \multicolumn{5}{|c|}{ Component } \\
\hline & 1 & 2 & 3 & 4 & 5 \\
\hline Kl Pell & 0,628 & $-0,045$ & 0,064 & $-0,216$ & $-0,444$ \\
\hline $\mathrm{Kl} \mathrm{Pel2}$ & 0,798 & 0,128 & $-0,186$ & 0,167 & $-0,106$ \\
\hline $\mathrm{Kl} \mathrm{Pel} 4$ & 0,654 & 0,270 & $-0,118$ & $-0,364$ & 0,382 \\
\hline $\mathrm{Kl}$ Pelf5 & 0,601 & 0,014 & 0,197 & $-0,704$ & $-0,120$ \\
\hline $\mathrm{Kl} \mathrm{Pel6}$ & 0,637 & $-0,331$ & $-0,337$ & $-0,185$ & 0,201 \\
\hline Kl Pel7 & 0,683 & $-0,403$ & 0,136 & 0,202 & 0,140 \\
\hline $\mathrm{Kl} \mathrm{Pel8}$ & 0,435 & $-0,720$ & 0,263 & 0,194 & $-0,183$ \\
\hline $\mathrm{Kl} \mathrm{Pel} 9$ & 0,681 & $-0,314$ & 0,246 & 0,012 & 0,181 \\
\hline $\mathrm{Kl}$ Pell0 & 0,676 & 0,189 & 0,373 & 0,035 & $-0,311$ \\
\hline Kl Pell1 & 0,342 & 0,632 & 0,357 & 0,151 & $-0,245$ \\
\hline $\mathrm{Kl}$ Pell2 & 0,735 & 0,107 & $-0,424$ & $-0,095$ & $-0,184$ \\
\hline $\mathrm{Kl}$ Pell3 & 0,679 & 0,184 & $-0,168$ & 0,358 & $-0,110$ \\
\hline $\mathrm{Kl}$ Pell14 & 0,668 & 0,390 & $-0,315$ & 0,240 & 0,156 \\
\hline Kl Pell5 & 0,803 & $-0,221$ & $-0,079$ & 0,140 & 0,098 \\
\hline $\mathrm{Kl}$ Pell17 & 0,435 & 0,283 & 0,534 & 0,068 & 0,548 \\
\hline
\end{tabular}

terlihat membentuk 5 (lima)

komponen, sedangkan yang diharapkan hanya membentuk 1 (satu) komponen saja. Maka dari itu proses analisis harus diulang dengan cara mengeluarkan itemitem yang dianggap tidak valid yaitu yang memiliki Measure of Sampling Adequacy (MSA) paling kecil dengan melihat output pada tabel Anti-images Matricespada output SPSS dibagian Anti-image Corellation. Terlihat bahwa item Kl_Pel8 memiliki MSA sebesar 0,499. Dengan demikian item tersebut yaitu pernyataan nomor 8 dari variabel kualitas pelayanan dikeluarkan dari analisis karena dinyatakan tidak valid.
Hasil Uji Validiatas Variabel Kualitas Pelayanan

\begin{tabular}{|c|c|c|c|c|}
\hline & \multicolumn{4}{|c|}{ Component } \\
\hline & 1 & 2 & 3 & 4 \\
\hline $\mathrm{Kl}$ Pell & 0,630 & $-0,071$ & 0,097 & $-0,430$ \\
\hline Kl Pel2 & 0,806 & 0,025 & $-0,250$ & 0,034 \\
\hline $\mathrm{Kl}$ Pel4 & 0,675 & 0,067 & 0,072 & $-0,027$ \\
\hline $\mathrm{Kl}$ Pel5 & 0,603 & $-0,020$ & 0,410 & $-0,570$ \\
\hline Kl Pel6 & 0,629 & $-0,539$ & $-0,019$ & 0,010 \\
\hline $\mathrm{Kl}$ Pel7 & 0,657 & $-0,314$ & 0,209 & 0,285 \\
\hline $\mathrm{Kl}$ Pel9 & 0,662 & $-0,235$ & 0,367 & 0,182 \\
\hline Kl Pel10 & 0,668 & 0,411 & 0,108 & $-0,187$ \\
\hline Kl Pell1 & 0,369 & 0,736 & 0,013 & $-0,062$ \\
\hline Kl Pell2 & 0,743 & $-0,092$ & $-0,390$ & $-0,236$ \\
\hline $\mathrm{Kl}$ Pell3 & 0,682 & 0,168 & $-0,379$ & 0,148 \\
\hline Kl Pell4 & 0,696 & 0,176 & $-0,385$ & 0,239 \\
\hline $\mathrm{Kl}$ Pell5 & 0,790 & $-0,240$ & $-0,023$ & 0,176 \\
\hline $\mathrm{Kl}$ Pell7 & 0,448 & 0,373 & 0,520 & 0,463 \\
\hline
\end{tabular}

Dari hasil output diatas terlihat membentuk 4 (empat) komponen sedangkan yang diharapkan hanya membentuk 1 (satu) komponen saja. Maka dari itu proses analisis harus diulang dengan cara mengeluarkan itemitem yang dianggap tidak valid yaitu yang memiliki Measure of Sampling Adequacy (MSA) paling kecil dengan melihat output pada tabel Anti-images Matricespada output SPSS dibagian Anti-image Corellation. Terlihat bahwa item Kl_Pel5 memiliki MSA sebesar 0,517. Dengan demikian item tersebut yaitu pernyataan nomor 5 dari variabel kualitas pelayanan dikeluarkan dari analisis karena dinyatakan tidak valid. 
Hasil Uji Validitas Variabel Kualitas Pelayanar

\begin{tabular}{|c|c|c|c|}
\hline \multirow{2}{*}{} & \multicolumn{3}{|c|}{ Component } \\
\cline { 2 - 4 } & 1 & 2 & 3 \\
\hline Kl_Pel1 & 0,611 & $-0,067$ & $-0,074$ \\
\hline Kl_Pel2 & 0,827 & 0,020 & $-0,177$ \\
\hline Kl_Pel4 & 0,655 & 0,070 & 0,006 \\
\hline Kl_Pel6 & 0,629 & $-0,540$ & $-0,009$ \\
\hline Kl_Pel7 & 0,665 & $-0,316$ & 0,343 \\
\hline Kl_Pel9 & 0,660 & $-0,234$ & 0,431 \\
\hline Kl_Pel10 & 0,656 & 0,413 & 0,021 \\
\hline Kl_Pel11 & 0,368 & 0,735 & $-0,002$ \\
\hline Kl_Pel12 & 0,738 & $-0,094$ & $-0,461$ \\
\hline Kl_Pel13 & 0,708 & 0,161 & $-0,253$ \\
\hline Kl_Pel14 & 0,719 & 0,169 & $-0,235$ \\
\hline Kl_Pel15 & 0,794 & $-0,243$ & 0,070 \\
\hline Kl_Pel17 & 0,450 & 0,374 & 0,667 \\
\hline
\end{tabular}

Dari hasil output diatas terlihat membentuk 3 (empat) komponen sedangkan yang diharapkan hanya membentuk 1 (satu) komponen saja. Maka dari itu proses analisis harus diulang dengan cara mengeluarkan itemitem yang dianggap tidak valid yaitu yang memiliki Measure of Sampling Adequacy (MSA) paling kecil dengan melihat output pada tabel Anti-images Matricespada output SPSS dibagian Anti-image Corellation. Terlihat bahwa item Kl_Pel17 memiliki MSA sebesar 0,693. Dengan demikian item tersebut yaitu pernyataan nomor 17 dari variabel kualitas pelayanan dikeluarkan dari analisis karena dinyatakan tidak valid.
Hasil Uji Validitas Variabel Kualitas Pelayanan

\begin{tabular}{|c|c|c|}
\hline & \multicolumn{2}{|c|}{ Component } \\
\hline & 1 & 2 \\
\hline Kl Pel1 & 0,621 & $-0,006$ \\
\hline Kl_Pel2 & 0,834 & 0,085 \\
\hline Kl_Pel4 & 0,643 & 0,042 \\
\hline Kl_Pel6 & 0,644 & $-0,508$ \\
\hline Kl_Pel7 & 0,660 & $-0,383$ \\
\hline Kl_Pel9 & 0,652 & $-0,322$ \\
\hline Kl_Pel10 & 0,648 & 0,417 \\
\hline Kl Pel11 & 0,351 & 0,724 \\
\hline Kl Pel12 & 0,758 & 0,047 \\
\hline Kl Pel13 & 0,716 & 0,241 \\
\hline Kl_Pel14 & 0,717 & 0,217 \\
\hline Kl_Pel15 & 0,797 & $-0,242$ \\
\hline
\end{tabular}

terlihat membentuk 2 (dua) komponen sedangkan yang diharapkan hanya membentuk 1 (satu) komponen saja. Maka dari itu proses analisis harus diulang dengan cara mengeluarkan itemitem yang dianggap tidak valid yaitu yang memiliki Measure of Sampling Adequacy (MSA) paling kecil dengan melihat output pada tabel Anti-images Matricespada output SPSS dibagian Anti-image Corellation. Terlihat bahwa item Kl_Pel11 memiliki MSA sebesar 0,746. Dengan demikian item tersebut yaitu pernyataan nomor 11 dari variabel kualitas pelayanan dikeluarkan dari analisis karena dinyatakan tidak valid.

Hasil Uji Validitas Variabel Kualitas Pelayanan

\begin{tabular}{|c|c|c|}
\hline \multirow{2}{*}{} & \multicolumn{2}{|c|}{ Component } \\
\cline { 2 - 3 } & 1 & 2 \\
\hline Kl_Pel1 & 0,619 & 0,164 \\
\hline Kl_Pel2 & 0,829 & $-0,098$ \\
\hline Kl_Pel4 & 0,646 & $-0,281$ \\
\hline Kl_Pel6 & 0,662 & 0,400 \\
\hline Kl_Pel7 & 0,669 & 0,485 \\
\hline Kl_Pel9 & 0,659 & 0,451 \\
\hline Kl_Pel10 & 0,630 & $-0,286$ \\
\hline Kl_Pel12 & 0,760 & $-0,226$ \\
\hline Kl_Pel13 & 0,709 & $-0,329$ \\
\hline Kl_Pel14 & 0,711 & $-0,374$ \\
\hline Kl_Pel15 & 0,809 & 0,155 \\
\hline
\end{tabular}


Dari hasil output diatas terlihat membentuk 2 (dua) komponen sedangkan yang diharapkan hanya membentuk 1 (satu) komponen saja. Maka dari itu proses analisis harus diulang dengan cara mengeluarkan itemitem yang dianggap tidak valid yaitu yang memiliki Measure of Sampling Adequacy (MSA) paling kecil dengan melihat output pada tabel Anti-images Matricespada output SPSS dibagian Anti-image Corellation. Terlihat bahwa item Kl_Pel6 memiliki MSA sebesar 0,795. Dengan demikian item tersebut yaitu pernyataan nomor 6 dari variabel kualitas pelayanan dikeluarkan dari analisis karena dinyatakan tidak valid

Hasil Uji Validitas Variabel Kualitas Pelayanan

\begin{tabular}{|c|c|c|}
\hline \multirow{2}{*}{} & \multicolumn{2}{|c|}{ Component } \\
\cline { 2 - 3 } & 1 & 2 \\
\hline Kl_Pel1 & 0,626 & 0,329 \\
\hline Kl_Pel2 & 0,827 & $-0,068$ \\
\hline Kl_Pel4 & 0,641 & $-0,383$ \\
\hline Kl_Pel7 & 0,656 & 0,514 \\
\hline Kl_Pel9 & 0,644 & 0,482 \\
\hline Kl_Pel10 & 0,663 & $-0,072$ \\
\hline Kl_Pel12 & 0,757 & $-0,268$ \\
\hline Kl_Pel13 & 0,733 & $-0,236$ \\
\hline Kl_Pel14 & 0,728 & $-0,367$ \\
\hline Kl Pel15 & 0,804 & 0,172 \\
\hline
\end{tabular}

Dari hasil output diatas terlihat membentuk 2 (dua) komponen sedangkan yang diharapkan hanya membentuk 1 (satu) komponen saja. Maka dari itu proses analisis harus diulang dengan cara mengeluarkan itemitem yang dianggap tidak valid yaitu yang memiliki Measure of Sampling Adequacy (MSA) paling kecil dengan melihat output pada tabel Anti-images Matricespada output SPSS dibagian Anti-image Corellation. Terlihat bahwa item Kl_Pel7 memiliki MSA sebesar
0,775. Dengan demikian item tersebut yaitu pernyataan nomor 7 dari variabel kualitas pelayanan dikeluarkan dari analisis karena dinyatakan tidak valid.

Hasil Uji Validitas Variabel Kualitas Pelayanan

\begin{tabular}{|c|c|}
\hline \multirow{2}{*}{} & Component \\
\cline { 2 - 2 } & 1 \\
\hline Kl_Pel1 & 0,621 \\
\hline Kl_Pel2 & 0,841 \\
\hline Kl_Pel4 & 0,665 \\
\hline Kl_Pel9 & 0,618 \\
\hline Kl_Pel10 & 0,677 \\
\hline Kl_Pel12 & 0,766 \\
\hline Kl_Pel13 & 0,755 \\
\hline Kl_Pel14 & 0,736 \\
\hline Kl Pel15 & 0,781 \\
\hline Pada tabel di atas
\end{tabular}
menunjukkan variabel kualitas pelayanan membentuk 1 (satu) komponen dengan 9 (sembilan) item pernyataan yang tersisa yaitu Kl_Pel1, Kl_Pel2, Kl_Pel4, Kl_Pel9, Kl_Pel10, Kl_Pel12, Kl_Pel13, Kl_Pel14 dan Kl_Pel15 kemudian setiap item memiliki nilai factor loading $>0,50$ sehingga kesembilan item pernyataan tersebut dianggap valid.

c. Hasil Uji Validitas Kepuasan Pelanggan

Hasil Uji Validitas Variabel Kepuasan Pelanggan

\begin{tabular}{|c|c|}
\hline & Component \\
\cline { 2 - 2 } & 1 \\
\hline Kp_Pel1 & 0,819 \\
\hline Kp_Pel2 & 0,766 \\
\hline Kp_Pel3 & 0,681 \\
\hline Kp_Pel4 & 0,710 \\
\hline
\end{tabular}

Pada tabel di atas menunjukkan variabel kepuasan pelanggan membentuk 1 (satu) komponen dengan 4 (empat) item pernyataan yaitu Kp_Pel1, Kp_Pel2, Kp_Pel3 dan Kp_Pel4 kemudian setiap item memiliki nilai factor loading > 0,50 sehingga keempat item pernyataan tersebut dianggap valid. 
d. Hasil Uji Validitas Loyalitas Pelanggan

Hasil Uji Validita Variabel Loyalitas Pelanggan

\begin{tabular}{|c|c|}
\hline & Component \\
\cline { 2 - 2 } & 1 \\
\hline KP1 & 0,816 \\
\hline KP2 & 0,635 \\
\hline KP3 & 0,727 \\
\hline KP4 & 0,663 \\
\hline KP5 & 0,672 \\
\hline KP6 & 0,828 \\
\hline
\end{tabular}

Pada tabel di atas menunjukkan variabel loyalitas pelanggan membentuk 1 (satu) komponen dengan 6 (enam) item pernyataan yaitu KP1, KP2, KP3, KP4, KP5 dan KP6 kemudian setiap item memiliki nilai factor loading > 0,50 sehingga keempat item pernyataan tersebut dianggap valid.

2. Hasil Uji Reliabilitas

\begin{tabular}{|c|c|c|c|}
\hline $\mathrm{N}_{0 .}$ & Variabel & Cronbach's Alpha & Keterangan \\
\hline 1. & Kualitas Produk $\left(X_{l}\right)$ & 0,724 & Reliabel \\
\hline 2. & Kualitas Pelayanan $\left(X_{2}\right)$ & 0,866 & Reliabel \\
\hline 3. & Kepuasan Pelanggan (Z) & 0,726 & Reliabel \\
\hline 4. & Loyalitas Pelanggan (Y) & 0,820 & Reliabel \\
\hline
\end{tabular}
dijelaskan dari hasil uji reliabilitas adalah sebagai berikut:

a. Variabel kualitas produk menunjukkan nilai cronbach's alpha sebesar 0,724 artinya variabel kualitas produk reliabel atau handal karena 0,724 lebih besar dari 0,60. Dapat dikatakan bahwa jawaban responden terhadap item pernyataan pada variabel ini konsisten atau stabil dari waktu ke waktu.

b. Variabel kualitas pelayanan menunjukkan nilai cronbach's alpha sebesar 0,866 artinya variabel kualitas pelayanan reliabel atau handal karena 0,866 lebih besar dari 0,60. Dapat dikatakan bahwa jawaban responden terhadap item pernyataan pada variabel ini konsisten atau stabil dari waktu ke waktu.

c. Variabel kepuasan pelanggan menunjukkan nilai cronbach's alpha sebesar 0,726 artinya variabel kepuasan pelanggan reliabel atau handal karena 0,726 lebih besar dari 0,60. Dapat dikatakan bahwa jawaban responden terhadap item pernyataan pada variabel ini konsisten atau stabil dari waktu ke waktu.

d. Variabel loyalitas pelanggan menunjukkan nilai cronbach's alpha sebesar 0,820 artinya variabel loyalitas pelanggan reliabel atau handal karena 0,820 lebih besar dari 0,60. Dapat dikatakan bahwa jawaban responden terhadap item pernyataan pada variabel ini konsisten atau stabil dari waktu ke waktu.

3. Hasil Analisis Regresi Berganda

a. Analisis Regresi Berganda Model 1

\begin{tabular}{|c|c|c|c|}
\hline \multicolumn{4}{|c|}{ Hasil Analisis Model I } \\
\hline Model & $\begin{array}{c}\text { Unstrandardized } \\
\text { Coefficients }\end{array}$ & $\begin{array}{c}\text { Strandardized } \\
\text { Coefficients }\end{array}$ & Sig. \\
\hline & B & Beta & \\
\hline 1 (Constant) & 1,072 & & 0,046 \\
\hline Kl_Pro $\left(X_{1}\right)$ & 0,125 & 0,109 & 0,408 \\
\hline $\mathrm{Kl}$ Pel $\left(\mathrm{X}_{2}\right)$ & 0,588 & 0,531 & 0,000 \\
\hline
\end{tabular}

tersebut maka diperoleh persamaa regresi sebagai berikut:

$\mathrm{Z}=\mathrm{a}+\mathrm{b} 1 \mathrm{X} 1+\mathrm{b} 2 \mathrm{X} 2$

$\mathrm{Z}=1,072+0,125 \mathrm{X} 1+0,588 \mathrm{X} 2$

Dimana:

$\mathrm{Z} \quad$ : kepuasan pelanggan

$\mathrm{X} 1 \quad$ : kualitas produk

X2 : kualitas pelayanan 
Dari persamaan di atas dapat dijelaskan sebagai berikut:

1) Nilai a atau konstan sebesar 1,072 menyatakan bahwa jika tidak ada pengauh kualitas produk (X1) atau kualitas pelayanan (X2), maka besarnya kepuasan pelanggan (Z) adalah 1,072.

2) Nilai b1 atau koefisien kualitas produk (X1) sebesar 0,125 bernilai positif menyatakan bahwa setiap kenaikan sebesar 1 satuan maka kualitas produk (X1) akan meningkatkan kepuasan pelanggan (Z) sebesar 0,125 .

3) Nilai b2 atau koefisien kualitas pelayanan (X2) sebesar 0,588 bernilai positif menyatakan bahwa setiap kenaikan sebesar 1 satuan maka kualitas pelayanan (X2) akan meningkatkan kepuasan pelanggan (Z) sebesar 0,588 .

b. Analisis Regresi Berganda Model 2

\begin{tabular}{|c|c|c|c|}
\hline \multirow{2}{*}{ Model } & $\begin{array}{c}\text { Unstrandardized } \\
\text { Coefficients }\end{array}$ & $\begin{array}{c}\text { Strandardized } \\
\text { Coefficients }\end{array}$ & \multirow{2}{*}{ Sig. } \\
\cline { 2 - 3 } & $\mathrm{B}$ & Beta & \\
\hline $1($ Constant $)$ & 0,334 & & 0,601 \\
\hline $\mathrm{Kl}$ _Pro $\left(\mathrm{X}_{1}\right)$ & 0,125 & 0,091 & 0,494 \\
\hline $\mathrm{K}$ I_Pel $\left(\mathrm{X}_{2}\right)$ & 0,688 & 0,522 & 0,000 \\
\hline
\end{tabular}

Berdasarkan hasil analisis tersebut maka diperoleh persamaa regresi sebagai berikut:

$\mathrm{Y}=\mathrm{a}+\mathrm{b} 1 \mathrm{X} 1+\mathrm{b} 2 \mathrm{X} 2$

$\mathrm{Y}=0,334+0,125 \mathrm{X} 1+0,688 \mathrm{X} 2$

Dimana:

Y : loyalitas pelanggan

$\mathrm{X} 1 \quad$ : kualitas produk

X2 : kualitas pelayanan

Dari persamaan diatas dapat dijelaskan sebagai berikut:

1) Nilai a atau konstan sebesar 0,334 menyatakan bahwa jika tidak ada pengauh kualitas produk (X1) atau kualitas pelayanan (X2), maka besarnya loyalitas pelanggan (Y) adalah 0,334 .

2) Nilai b1 atau koefisien kualitas produk (X1) sebesar 0,125 bernilai positif menyatakan bahwa setiap kenaikan sebesar 1 satuan maka kualitas produk (X1) akan meningkatkan loyalitas pelanggan (Y) sebesar 0,125 .

3) Nilai b2 atau koefisien kualitas pelayanan (X2) sebesar 0,688 bernilai positif menyatakan bahwa setiap kenaikan sebesar 1 satuan maka kualitas pelayanan (X2) akan meningkatkan loyalitas pelanggan (Y) sebesar 0,588.

c. Analisis Regresi Berganda Model 3

\begin{tabular}{|c|c|c|c|}
\hline \multirow{2}{*}{ Model } & $\begin{array}{c}\text { Unsil Analisis Model III } \\
\text { Coefficients }\end{array}$ & $\begin{array}{c}\text { Strandardized } \\
\text { Coefficients }\end{array}$ & \multirow{2}{*}{ Sig. } \\
\cline { 2 - 3 } & $\mathrm{B}$ & Beta & \\
\hline 1 (Constant) & 0,064 & & 0,922 \\
\hline $\mathrm{Kl}$ Pro $\left(\mathrm{X}_{1}\right)$ & 0,094 & 0,068 & 0,606 \\
\hline $\mathrm{Kl}$ Pel $\left(\mathrm{X}_{2}\right)$ & 0,540 & 0,410 & 0,008 \\
\hline $\mathrm{Kep}$ Pel $(\mathrm{Z})$ & 0,251 & 0,211 & 0,118 \\
\hline
\end{tabular}

Berdasarkan hasil analisis tersebut maka diperoleh persamaa regresi sebagai berikut:

$\mathrm{Y}=\mathrm{a}+\mathrm{b} 1 \mathrm{X} 1+\mathrm{b} 2 \mathrm{X} 2+\mathrm{b} 3 \mathrm{Z}$

$\mathrm{Y}=0,064+0,094 \mathrm{X} 1+0,540 \mathrm{X} 2+$ $0,251 Z$

Dimana:

$\mathrm{Y} \quad$ : loyalitas pelanggan

$\mathrm{X} 1 \quad$ : kualitas produk

X2 : kualitas pelayanan

$\mathrm{Z} \quad$ : kepuasan pelanggan

Dari persamaan diatas dapat dijelaskan sebagai berikut:

1) Nilai a atau konstan sebesar 0,064 menyatakan bahwa jika tidak ada pengauh kualitas produk (X1) atau kualitas pelayanan (X2) atau kepuasan pelanggan (Z), maka besarnya loyalitas pelanggan (Y) adalah 0,064. 
2) Nilai b1 atau koefisien kualitas produk (X1) sebesar 0,094 bernilai positif menyatakan bahwa setiap kenaikan sebesar 1 satuan maka kualitas produk (X1) akan meningkatkan loyalitas pelanggan (Y) sebesar 0,094 .

3) Nilai b2 atau koefisien kualitas pelayanan (X2) sebesar 0,540 bernilai positif menyatakan bahwa setiap kenaikan sebesar 1 satuan maka kualitas pelayanan (X2) akan meningkatkan loyalitas pelanggan (Y) sebesar 0,540 .

4) Nilai b3 atau koefisien kepuasan pelanggan (Z) sebesar 0,251 bernila positif menyatakan bahwa setiap kenaikan sebesar 1 satuan maka kepuasan pelanggan (Z) akan meningkatkan loyalitas pelanggan (Y) sebesar 0,251.

\section{Hasil Uji Mediasi}

a. Pengaruh kualitas produk (X1) terhadap loyalitas pelanggan (Y) dimediasi kepuasan pelanggan (Z).

Untuk melakukan pengujian tersebut menggunakan analisis jalur dengan membandingkan pengaruh langsung kualitas produk (X1) terhadap loyalitas pelanggan (Y) dengan membandingkan pengaruh tidak langsung melalui kepuasan pelanggan sebagai variabel mediasi (Z). Pengujian dilakukan dengan tahapan sebagi berikut:

1) Pengaruh langsung, yaitu kualitas produk (X1) terhadap loyalitas pelanggan (Y) terdapat nilai koefisien sebesar 0,091 dilihat dari tabel hasil analisis regresi berganda model 2 pada bagian kolom standardized coefficients beta.
2) Pengaruh tidak langsung, yaitu kualitas produk (X1) terhadap loyalitas pelanggan (Y) melalui kepuasan pelanggan $(\mathrm{Z})$ terdapat nilai koefisien sebesar 0,022 didapat dari $0,109 \times 0,211=$ 0,022 .

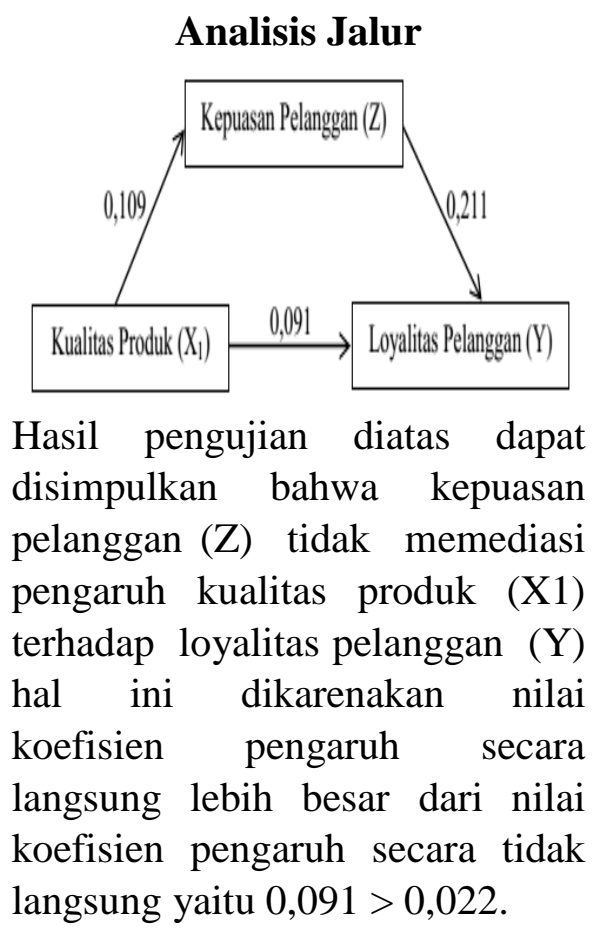

b. Pengaruh kualitas pelayanan (X2) terhadap loyalitas pelanggan (Y) dimediasi kepuasan pelanggan (Z).

Untuk melakukan pengujian tersebut menggunakan analisis jalur dengan membandingkan pengaruh langsung kualitas pelayanan (X2) terhadap loyalitas pelanggan (Y) dengan membandingkan pengaruh tidak langsung melalui kepuasan pelanggan sebagai variabel mediasi (Z). Pengujian dilakukan dengan tahapan sebagi berikut:

1) Pengaruh langsung, yaitu kualitas pelayanan (X2) terhadap loyalitas pelanggan (Y) terdapat nilai koefisien sebesar 0,522 dilihat dari tabel hasil analisis regresi berganda model 2 
pada bagian kolom standardized coefficients beta.

2) Pengaruh tidak langsung, yaitu kualitas pelayanan (X2) terhadap loyalitas pelanggan (Y) melalui kepuasan pelanggan $(Z)$ terdapat nilai koefisien sebesar 0,112 didapat dari $0,531 \times 0,211=0,112$.

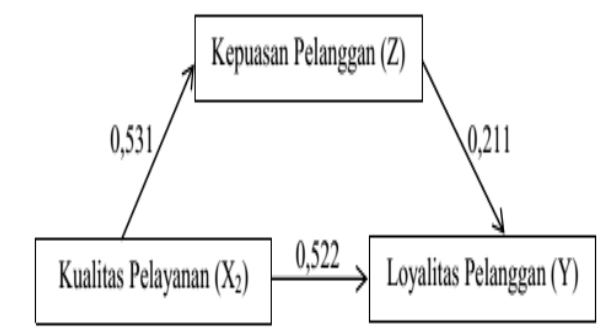

Hasil pengujian diatas dapat disimpulkan bahwa kepuasan pelanggan (Z) tidak memediasi pengaruh kualitas pelayanan (X2) terhadap loyalitas pelanggan (Y) hal ini dikarenakan nilai koefisien pengaruh secara langsung lebih besar dari nilai koefisien pengaruh secara tidak langsung yaitu $0,522>0,112$.

\section{Hasil Uji Parsial (Uji T)}

a. Hasil Uji Parsial Model 1

Hasil Uji Signifikansi Parsial (Uji t) Model I

\begin{tabular}{|c|c|}
\hline Model & Sig. \\
\hline $1($ Constant $)$ & 0,046 \\
\hline Kl_Pro $\left(\mathrm{X}_{1}\right)$ & 0,408 \\
\hline $\mathrm{Kl}$ Pel $\left(\mathrm{X}_{2}\right)$ & 0,000 \\
\hline
\end{tabular}

Berdasarkan nilai signifikansi yang dihasilkan uji secara parsial dapat dijelaskan sebagai berikut:

1) Variabel kualitas produk mempunyai nilai sig. sebesar 0,408 lebih besar dari 0,05 maka dapat disimpulkan bahwa secara parsial variabel kualitas produk tidak berpengaruh secara signifikan terhadap kepuasan pelanggan.

2) Variabel kualitas pelayanan mempunyai nilai sig. sebesar 0,000 lebih kecil dari 0,05 maka dapat disimpulkan bahwa secara parsial variabel kualitas pelayanan berpengaruh secara signifikan terhadap kepuasan pelanggan.

b. Hasil Uji Parsial Model 2 Hasil Uji Signifikansi Parsial (Uji t) Model II

\begin{tabular}{|c|c|}
\hline Model & Sig. \\
\hline 1 (Constant) & 0,601 \\
\hline $\mathrm{Kl}$ Pro $\left(\mathrm{X}_{1}\right)$ & 0,494 \\
\hline $\mathrm{Kl}$ Pel $\left(\mathrm{X}_{2}\right)$ & 0,000 \\
\hline
\end{tabular}

Berdasarkan nilai signifikansi yang dihasilkan uji secara parsial dapat dijelaskan sebagai berikut:

1) Variabel kualitas produk mempunyai nilai sig. sebesar 0,494 lebih besar dari 0,05 maka dapat disimpulkan bahwa secara parsial variabel kualitas produk tidak berpengaruh secara signifikan terhadap loyalitas pelanggan.

2) Variabel kualitas pelayanan mempunyai nilai sig. sebesar 0,000 lebih kecil dari 0,05 maka dapat disimpulkan bahwa secara parsial variabel kualitas pelayanan berpengaruh secara signifikan terhadap loyalitas pelanggan.

c. Hasil Uji Parsial Model 3

Hasil Uji Signifikansi Parsial (Uji t) Model III

\begin{tabular}{|c|c|}
\hline Model & Sig. \\
\hline 1 Constant $)$ & 0,922 \\
\hline Kl_Pro $\left(\mathrm{X}_{1}\right)$ & 0,606 \\
\hline Kl_Pel $\left(\mathrm{X}_{2}\right)$ & 0,008 \\
\hline Kep_Pel $(\mathrm{Z})$ & 0,118 \\
\hline
\end{tabular}

Berdasarkan nilai signifikansi yang dihasilkan uji secara parsial dapat dijelaskan bahwa variabel kepuasan pelanggan mempunyai nilai sig. sebesar 0,118 lebih besar dari 0,05 maka dapat disimpulkan bahwa secara parsial variabel kepuasan pelanggan tidak 
berpengaruh secara signifikan terhadap loyalitas pelanggan.

Hasil Kesimpulan Hipotesis 1.5

\begin{tabular}{|c|c|c|c|c|c|}
\hline $\begin{array}{c}\text { Variabel } \\
\text { Independen }\end{array}$ & $\begin{array}{c}\text { Variabel } \\
\text { Dependen }\end{array}$ & $\begin{array}{c}\text { Arah } \\
\text { Pengaruh }\end{array}$ & Sig. & Alpha & Kesimpulan \\
\hline $\begin{array}{c}\text { Kualitas } \\
\text { Produk }\left(X_{\mathrm{I}}\right)\end{array}$ & $\begin{array}{c}\text { Kepuasan } \\
\text { Pelanggan } \\
\text { (Z) }\end{array}$ & Positif $(+)$ & 0,408 & 0,05 & $\begin{array}{c}\text { Menolak } \\
\mathrm{H}_{1} \text { atau } \\
\text { Menerima } \\
\mathrm{HO}_{1} \\
\end{array}$ \\
\hline $\begin{array}{c}\text { Kualitas } \\
\text { Pelayanan } \\
\left(X_{2}\right)\end{array}$ & $\begin{array}{c}\text { Kepuasan } \\
\text { Pelanggan } \\
\text { (Z) }\end{array}$ & Positif $(+)$ & 0,000 & 0,05 & $\begin{array}{c}\text { Menerima } \\
\mathrm{H}_{2} \text { atauMenol } \\
\text { ak } \mathrm{HO}_{2}\end{array}$ \\
\hline $\begin{array}{c}\text { Kepuasan } \\
\text { Pelanggan } \\
\text { (Z) }\end{array}$ & $\begin{array}{l}\text { Loyalitas } \\
\text { Pelanggan } \\
\text { (Y) }\end{array}$ & Positif $(+)$ & 0,118 & 0,05 & $\begin{array}{c}\text { Menolak } \\
\mathrm{H}_{3} \text { atau } \\
\text { Menerima } \\
\mathrm{HO}_{3}\end{array}$ \\
\hline $\begin{array}{c}\text { Kualitas } \\
\text { Produk }\left(X_{\mathrm{l}}\right)\end{array}$ & $\begin{array}{l}\text { Loyalitas } \\
\text { Pelanggan } \\
\text { (Y) }\end{array}$ & Positif $(+)$ & 0,494 & 0,05 & $\begin{array}{c}\text { Menolak } \\
\mathrm{H}_{4} \text { atau } \\
\text { MenerimaHo } \\
4\end{array}$ \\
\hline $\begin{array}{c}\text { Kualitas } \\
\text { Pelayanan } \\
\left(\mathrm{X}_{2}\right)\end{array}$ & $\begin{array}{l}\text { Loyalitas } \\
\text { Pelanggan } \\
\text { (Y) }\end{array}$ & Positif $(+)$ & 0,000 & 0,05 & $\begin{array}{c}\text { Menerima } \\
\mathrm{H}_{5} \text { atau } \\
\text { Menolak } \mathrm{H}_{5}\end{array}$ \\
\hline
\end{tabular}

Dari tabel diatas dapat terlihat pengaruh variabel independen terhadap variabel dependen, variabel kualitas produk tidak berpengaruh signifikan terhadap kepuasan pelanggan karena memiliki nilai sig. $0,408>0,05$, variabel kualitas pelayanan berpengaruh signifikan terhadap kepuasan pelanggan karena memiliki nilai sig. $0,000<0,05$, variabel kepuasan pelanggan tidak berpengaruh signifikan terhadap loyalitas pelanggan karena memiliki niali sig. $0,118>0,05$, variabel kualitas produk tidak berpengaruh signifikan terhadap loyalitas pelanggan karena memiliki nilai sig. 0,494>0,05 dan kualitas pelayanan berpengaruh signifikan terhadap loyalitas pelanggan karena memiliki nilai sig. $0,000<0,05$.
Hasil Kesimpulan Hipotesis 6-7

\begin{tabular}{|c|c|c|c|c|}
\hline & \multicolumn{2}{|c|}{ Standardized Coefficient } & & \\
\hline Variabel & $\begin{array}{l}\text { Pengaruh } \\
\text { Langsung }\end{array}$ & $\begin{array}{l}\text { Pengaruh } \\
\text { Tidak } \\
\text { Langsung }\end{array}$ & Hasil & Kesimpualan \\
\hline$X_{1}-Y$ & 0,091 & & Tidak terjadi & Menolak \\
\hline$X_{1}-Z-Y$ & & 0,022 & mediasi & $\begin{array}{c}\mathrm{H}_{6} \text { atau } \\
\text { Menerima } \\
\mathrm{H}_{6}\end{array}$ \\
\hline$X_{2}-Y$ & 0,522 & & Tidak terjadi & Menolak \\
\hline$X_{2}-Z-Y$ & & 0,112 & mediasi & $\begin{array}{c}\mathrm{H}_{7} \text { atau } \\
\text { Menerima } \\
\mathrm{HO}_{7}\end{array}$ \\
\hline
\end{tabular}

Dari tabel diatas dapat terlihat bahwa variabel kepuasan pelanggan tidak memediasi pengaruh kualitas produk terhadap loyalitas pelanggan karena nilai pengaruh langsung lebih besar dari nilai pengaruh tidak langsung yaitu 0,091 > 0,022 dan variabel kepuasan pelanggan tidak memediasi pengaruh kualitas pelayanan terhadap loyalitas pelanggan karena nilai pengaruh langsung lebih besar dari nilai pengaruh tidak langsung yaitu $0,522>0,112$.

\section{Hasil Uji Koefisien Determinasi}

Hasil Perhitungan $\mathrm{R}^{2}$

\begin{tabular}{|c|c|}
\hline Model & Adjusted R Square \\
\hline I & 0,338 \\
\hline II & 0,313 \\
\hline III & 0,331 \\
\hline
\end{tabular}

Pada tabel diatas merupakan gambaran R2 yang digunakan untuk menganalisis seberapa besar kontribusi variabel independen terhadap variabel dependen. Pada model I merupakan hasil Adjusted $R$ Square dari regresi kualitas produk (X1) dan kualitas pelayanan (X2) terhadap kepuasan pelanggan $(\mathrm{Z})$ yaitu 0,338 yang artinya variabel kualitas produk (X1) dan kualitas pelayanan (X2) mampu menjelaskan variabel kepuasan pelanggan (Z) sebesar 0,338 atau $33,8 \%$ dan sisanya $\quad(100 \%-33,8 \%=66,2 \%)$ dijelaskan oleh variabel lain yang tidak diteliti dalam penelitian ini. 
Pada model II merupakan hasil Adjusted $R$ Square dari regresi kualitas produk (X1) dan kualitas pelayanan (X2) terhadap loyalitas pelanggan (Y) yaitu 0,313 yang artinya variabel kualitas produk (X1) dan kualitas pelayanan (X2) mampu menjelaskan variabel loyalitas pelanggan (Y) sebesar 0,313 atau 31,3\% dan sisanya $\quad(100 \%-31,3 \%=68,7 \%)$ dijelaskan oleh variabel lain yang tidak diteliti dalam penelitian ini.

Pada model III merupakan hasil Adjusted $R$ Square dari regresi kualitas produk (X1), kualitas pelayanan (X2) dan kepuasan pelanggan $(Z)$ terhadap loyalitas pelanggan (Y) yaitu 0,331 yang artinya variabel kualitas produk (X1), kualitas pelayanan (X2) dan kepuasan pelanggan (Z) mampu menjelaskan variabel loyalitas pelanggan (Y) sebesar 0,331 atau $33,1 \%$ dan sisanya $\quad(100 \%-33,1 \%=66,9 \%)$ dijelaskan oleh variabel lain yang tidak diteliti dalam penelitian ini.

\section{Pembahasan}

1. Pengaruh kualitas produk terhadap kepuasan pelanggan

Dari uji hipotesis yang dilakukan kualitas produk tidak mempunyai pengaruh yang signifikan terhadap kepuasan pelanggan dalam menkonsumsi produk dari Waroeng Spesial Sambal "SS" cabang Veteran Yogyakarta Hal ini menentukan tingkat kepuasan pelanggan. Pada saat terjadi adanya kegagalan produk maka pelanggan tidak teralu berharap adanya kompensasi setelah terjadi kegagalan produk.

2. Pengaruh kualitas pelayanan terhadap kepuasan pelanggan

Dari uji hipotesis yang dilakukan kualitas pelayana mempunyai pengaruh yang positif dan signifikan terhadap kepuasan pelanggan dalam menggunakan jasa dari Waroeng Spesial Sambal "SS" cabang Veteran Yogyakarta. Hal in menunjukkan bahwa kualitas pelayanan menentukan tingkat kepuasan pelanggan.Dengan perilaku karyawan yang baik maka diharapkan pelanggan akan merasa dihargai, diperhatikan dan dilayani sesuai kebutuhan pelanggan sehingga pelanggan cenderung mengalami kepuasan yang lebih besar pada saat diberikan pelayanan yang baik.

3. Pengaruh kepuasan pelanggan terhadap loyalitas pelanggan

Dari hasil uji hipotesis yang dilakukan kepuasan pelanggan tidak mempunyai pengaruh yang signifikan terhadap loyalitas pelanggan dalam menkonsumsi produk atau jasa dari Waroeng Spesial Sambal "SS" cabang Veteran Yogyakarta. Hal ini menunjukkan bahwa kepuasan yang dirasakan pelanggan setelah menggunakan produk dan jasa yang diberikan tidak lantas membuat pelanggan melakukan pembelian ulang kemungkinan pelanggan mencari alternatif lain agar kebutuhannya benarbenar terpenuhi sesuai dengan yang diharapkan.

4. Pengaruh kualitas produk terhadap loyalitas pelanggan

Dari hasil uji hipotesis yang dilakukan kualitas produk tidak berpengaruh signifikan terhadap loyalitas pelanggan dalam menkonsumsi produk dari Waroeng Spesial Sambal "SS" cabang Veteran Yogyakarta. Hal ini menunjukkan bahwa kualitas produk tidak menentukan tingkat loyalitas pelanggan. Pada saat terjadi adanya kegagalan produk maka pelanggan tidak teralu berharap adanya 
kompensasi setelah terjadi kegagalan produk.

5. Pengaruh kualitas pelayanan terhadap loyalitas pelanggan

Dari uji hipotesis yang dilakukan kualitas pelayanan mempunyai pengaruh yang positif dan signifikan terhadap loyalitas pelanggan dalam menggunaka jasa dari Waroeng Spesial Sambal "SS" cabang Veteran Yogyakarta. Hal ini menunjukkan bahwa kualitas pelayanan menentukan tingkat loyalitas pelanggan. Dengan perilaku karyawan yang baik maka diharapkan pelanggan akan merasa dihargai, diperhatikan dan dilayani sesuai kebutuhan pelanggan sehingga pelanggan cenderung loyal pada saat diberikan pelayanan yang baik.

6. Pengaruh kualitas produk, kualitas pelayanan dan kepuasan pelanggan terhadap loyalitas pelanggan

Hal ini digambarkan analisis jalur yang membentuk mediasi dengan uji regresi linear berganda, dan hasilnya dari kedua variabel independen yaitu kualitas produk dan kualitas pelayanan melalui variabel mediasi yaitu kepuasan pelanggan menunjukkan hasil bahwa tidak ada variabel independen yang menunjukkan adanya pengaruh melalui variabel mediasi terhadap loyalitas pelanggan. Hal ini memiliki arti bahwa pelanggan yang merasakan kualitas produk dan kualitas pelayanan yang diberikan Waroeng Spesial Sambal "SS" cabang Veteran Yogyakarta tidak harus merasakan kepuasan pelanggan terlebih dahulu untuk menjadi pelanggan yang loyal. Dengan kata lain kualitas produk dan kualitas pelayanan diberikan Waroeng Spesial Sambal "SS" cabang Veteran Yogyakarta mempengaruhi langsung terhadap loyalitas pelanggan tanpa melalui kepuasan pelanggan.

\section{KESIMPULAN DAN SARAN}

\section{Kesimpulan}

1. Kualitas produk tidak berpengaruh signifikan terhadap kepuasan pelanggan.

2. Kualitas pelayanan berpengaruh signifikan terhadap kepuasan pelanggan.

3. Kepuasan pelanggan tidak berpengaruh signifikan terhadap loyalitas pelanggan.

4. Kualitas produk tidak berpengaruh signifikan terhadap loyalitas pelanggan.

5. Kualitas pelayanan berpengaruh signifikan terhadap loyalitas pelanggan.

6. Kepuasan pelanggan tidak memediasi pengaruh kualitas produk terhadap loyalitas pelanggan.

7. Kepuasan pelanggan tidak memediasi pengaruh kualitas pelayanan terhadap loyalitas pelanggan.

\section{Saran}

1. Banyaknya jumlah responden yang menjawab setuju terhadap seluruh variabel penelitian (kualitas produk, kualitas pelayanan, kepuasan pelanggan dan loyalitas pelanggan) diharapkan restoran Waroeng Spesial Sambal "SS" cabang Veteran Yogyakarta melalui karyawan sebagai pengantar jasa dapat meningkatkan kualitas produk dan kualitas pelayanan serta mempertahankannya agar dapat memenuhi kebutuhan dan keinginan konsumen.

2. Pada penelitian selanjutnya tidak terbatas fokus pada satu cabang restoran saja tetapi akan lebih baik jika diteliti semua cabang yang ada.

3. Pada penelitian selanjutnya diharapkan dapat mengembangkan penelitian ini 
dengan melakukan penelitian pada faktor-faktor lainnya.

\section{DAFTAR PUSTAKA}

Irnandha, Aris. (2016). Pengaruh Kualitas

Layanan Terhadap Loyalitas

Pelanggan yang di Mediasi oleh

Kepuasan Pelanggan Jasa

Pengiriman Jalur Darat (Studi

Kasus Kepuasan Pelanggan JNE

Cabang Hijrah Sagan Yogyakarta).

Skripsi. Yogyakarta: Universitas

Negeri Yogyakarta.

Kotler, Philip dan Kevin Lane Keller.

(2009). Manajemen Pemasaran.

Jakarta: Erlangga.

Lovelock, Christopher, Jochen Wirtz dan

Jacky Mussry. (2013). Pemasaran

Jasa. Jakarta: Erlangga.

Lupiyoadi, Rambat. (2013). Manajemen

Pemasaran Jasa. Jakarta: Salemba

Empat.

Soedjas, Triwibowo. (2104). Layanan

Wow untuk Pelanggan. Jakarta:

Media Pressindo.

Sulistyaningrum, Utami. (2014). Pengaruh

Kualias Produk dan Layanan

Terhadap Kepuasan Konsumen di

Restoran Koki Tappanyaki

Express. Skripsi. Yogyakarta:

Universitas Negeri Yogyakarta.

Yamit, Zulian. (2004). Manajemen

Kualitas Produk dan Jasa.

Yogyakarta: Ekonisia. 